\title{
Article \\ Biocontrol Potential and Catabolic Profile of Endophytic Diaporthe eres Strain 1420 S from Prunus domestica L. in Poland-A Preliminary Study
}

\author{
Barbara Abramczyk 1,*(D), Anna Marzec-Grządziel 1(D), Jarosław Grządziel 1(D), Ewa Król ${ }^{2}$, Anna Gałązka ${ }^{1}$ (D) \\ and Wiesław Oleszek ${ }^{3}$ (D)
}

1 Department of Agricultural Microbiology, Institute of Soil Science and Plant Cultivation-State Research Institute, Czartoryskich 8, 24-100 Puławy, Poland; agrzadziel@iung.pulawy.pl (A.M.-G.); jgrzadziel@iung.pulawy.pl (J.G.); agalazka@iung.pulawy.pl (A.G.)

2 Department of Plant Protection, University of Life Sciences in Lublin, Leszczyńskiego 7, 20-069 Lublin, Poland; ewa.krol@up.lublin.pl

3 Department of Biochemistry and Crop Quality, Institute of Soil Science and Plant Cultivation-State Research Institute, Czartoryskich 8, 24-100 Puławy, Poland; wieslaw.oleszek@iung.pulawy.pl

* Correspondence: babramczyk@iung.pulawy.pl; Tel.: +48-81-478-6960

check for updates

Citation: Abramczyk, B.

Marzec-Grządziel, A.; Grządziel, J.; Król, E.; Gałązka, A.; Oleszek, W. Biocontrol Potential and Catabolic Profile of Endophytic Diaporthe eres Strain 1420 from Prunus domestica L. in Poland-A Preliminary Study. Agronomy 2022, 12, 165. https:// doi.org/10.3390/agronomy12010165 Academic Editor: Katarzyna Turnau Received: 7 December 2021 Accepted: 6 January 2022 Published: 10 January 2022

Publisher's Note: MDPI stays neutral with regard to jurisdictional claims in published maps and institutional affiliations.

Copyright: (c) 2022 by the authors. Licensee MDPI, Basel, Switzerland. This article is an open access article distributed under the terms and conditions of the Creative Commons Attribution (CC BY) license (https:// creativecommons.org/licenses/by/ $4.0 /)$.

\begin{abstract}
Recently, Diaporthe has been considered the most frequently isolated genera of endophytic fungi, having a broad spectrum of host plants and a worldwide distribution. The endophytic $\mathrm{Di}$ aporthe strain used in the present work came from the Fungal Collection of Phytopathology and Mycology Subdepartment, University of Life Sciences in Lublin (Poland), and was isolated from healthy Prunus domestica shoots during previous studies. Due to the possibility of using the Diaporthe endophytes as a promising option for plant disease management, the main goal of the research was to study the antagonistic effect of endophytic Diaporthe strain against six phytopathogens: Verticillium dahliae, Botrytis cinerea, Fusarium avenaceum, F. sprotrichioides, Alternaria alternata, and Trichothecium roseum based on the dual culture assay and to determine the catabolic profile of the endophyte by using Biolog FF Plates. The dual-culture test assay revealed the ability of the endophytic Diaporthe to limit the growth of all tested pathogens. The growth inhibition percentage ranged from $20 \%$ ( $V$. dahliae) to $40 \%$ (T. roseum). A distinct zone of inhibition occurred between the endophytic Diaporthe and the pathogens T. roseum, V. dahliae, and B. cinerea in the co-growth combinations. As for the catabolic profile results, the most intensive utilization of carbon substrates was observed after $168 \mathrm{~h}$ of incubation. The growth of the analyzed strain was observed on 79 media containing carbohydrates, carboxylic acids, amino acids, amines and amides, polymers, and others. The most effective decomposition was observed in the polymers group, the least in amines and amides. Molecular identification indicated that this strain was closely related to the Diaporthe eres species complex.
\end{abstract}

Keywords: antagonistic activity; dual culture assay; Biolog FF Plates; carbon substrate utilization; Phomopsis-like morph; fruit trees

\section{Introduction}

In recent decades, endophytic fungi have attracted the attention of scientists around the world due to their very positive effect on the host plants, stress resistance induction, growth promotion, plant protection, and metabolite production [1-6]. Some endophytic fungi colonize plant tissues without causing disease symptoms, and they occur in a wide range of plant species and habitats [7,8]. Recently, the use of endophytes as biocontrol agents has drawn special attention as an attractive option for management of some plant diseases, resulting in minimal impact on the environment [9]. Among endophytic fungi, Diaporthe is one of the most frequently isolated genera [10]. It has been widely investigated and has proved to produce a broad range of valuable compounds with different bioactivities, which was recently summarized in the extensive review by $\mathrm{Xu}$ et al. [11].These 
authors showed that the genus Diaporthe and its anamorph Phomopsis are regarded as potential sources for producing diverse bioactive metabolites. In the past ten years, a total of 335 bioactive secondary metabolites have been isolated both from known species of Diaporthe and Phomopsis and from unidentified ones. Overall, there are 106 bioactive compounds derived from Diaporthe and 246 from Phomopsis, while 17 compounds are found in both of them. They are classified into polyketides, terpenoids, steroids, macrolides, ten-membered lactones, alkaloids, flavonoids, and fatty acids.

Diaporthe Nitschke, and its asexual Phomopsis-like morph have been often described as plant pathogens, saprobes, and endophytes in a wide range of plant hosts [10,12-17]. For many years, their identification has been based on morphological features and host-plant associations [12]. Recently, multi-locus DNA data analysis combined with morphological characterization and host associations has been employed for species delimitation in the genus [13,15,17-29]. Although several endophytic Diaporthe species have been described as endophytes on woody plants worldwide [3,20,30-35], there is no available information concerning endophytic Diaporthe on Prunus domestica in Poland or worldwide.

Since endophytic Diaporthe species are known as a valuable source of bioactive metabolites and are likely to be promising agents in the development of a biological plant protection products or bio fertilizers, the knowledge of its nutritional requirements and antagonistic activity against phytopathogens seems crucial. Therefore, the main goal of this research was (i) to test the antagonistic activity of endophytic Diaporthe strain against common phytopathogens based on the dual culture assay and (ii) to determine the catabolic profile of the strain, by using Biolog FF Plates.

\section{Materials and Methods}

\subsection{Fungal Isolation}

The endophytic Diaporthe strain was isolated from healthy P. domestica shoots during previous studies conducted on fungi from fruit plants in Poland [14]. The strain was isolated following the protocol described by Król [36]. Briefly, shoot fragments were cut into small pieces, then washed under running tap water, surface-disinfected for $30 \mathrm{~s}$ in a sodium hypochlorite solution (10\%), and washed three times for $3 \mathrm{~min}$ in sterile distilled water, then plated on potato dextrose agar (PDA, Difco) and incubated at $25^{\circ} \mathrm{C}$ in the dark for 5 days. When colonies formed, each mycelium was transferred to a new PDA Petri dish and a number was assigned. The selected isolate differed from the others by very poor sporulation after isolation, which is often associated with endophytic colonization of host plants. Single spore cultures were obtained as described previously [36,37].

\subsection{DNA Extraction, PCR Amplification, and Sequencing}

DNA was extracted from the single spore mycelia growth on PDA at $25^{\circ} \mathrm{C}$ for 7 days using the FastDNA ${ }^{\circledR}$ SPIN Kit and the FastPrep ${ }^{\circledR}$ Instrument (Qbiogene, Inc., Irvine, CA, USA), following the manufacturer's instructions. DNA amplification was performed in a $25 \mu \mathrm{L}$ reaction volume containing $12.5 \mu \mathrm{L}$ of DreamTaq ${ }^{\mathrm{TM}}$ Green PCR Master Mix (2X) (Thermo Scientific, Waltham, MA, USA), $1 \mu \mathrm{L}$ of each primer $(10 \mu \mathrm{M}), 1 \mu \mathrm{L}$ of genomic DNA $(5 \mathrm{ng} / \mu \mathrm{L})$, and $9.5 \mu \mathrm{L}$ of purified water. For this research, 4 loci were amplified and sequenced: the internal transcribed spacer region (ITS) of the nuclear ribosomal RNA gene, part of the translation elongation factor 1- $\alpha$ gene (TEF1), part of the $\beta$-tubulin gene (TUB), and part of calmodulin gene (CAL). The ITS region was amplified using primers ITS1: TCCGTAGGTGAACCTGCGG, ITS4: TCCTCCGCTTATTGATATGC [38], Bt-2a: GGTAACCAAATCGGTGCTGCTTTC, and Bt-2b: ACCCTCAGTGTAGTGACCCTTGGC was used to amplify $\beta$-tubulin gene [39]. TEF1 was amplified with the primers EF1-728F: CATCGAGAAGTTCGAGAAGG, EF1-986R: TACTTGAAGGAACCCTTACC and calmodulin gene with CAL-228F: GAGTTCAAGGAGGCCTTCTCCC and CAL-737R: CATCTTCTGGCCATCATGG [40]. The PCR conditions were as follows: $95^{\circ} \mathrm{C}$ for $3 \mathrm{~min}$, followed by 39 cycles of $95{ }^{\circ} \mathrm{C}$ for $30 \mathrm{sec}, 55^{\circ} \mathrm{C}$ (ITS, CAL) or $58^{\circ} \mathrm{C}$ (TEF1, TUB) for $50 \mathrm{sec}, 72{ }^{\circ} \mathrm{C}$ for $1 \mathrm{~min}$, and final extension at $72{ }^{\circ} \mathrm{C}$ for $10 \mathrm{~min}$. The obtained PCR products were sequenced 
at Genomed S.A. (Warsaw, Poland). The obtained DNA sequences of each region were deposited in the GenBank with the accession numbers MW664034 (ITS), OK506723 (TEF1), OK506724 (TUB), OK490500 (CAL). Bioinformatic analyses were made with the use of Bionumerics 7.6 (Applied Maths NV., Sint-Martens-Latem, Belgium) and SEED v.2.1.05 (Institute of Microbiology CAS, Prague, Czech Republic) software. The obtained sequences were compared to the NCBI GenBank.

\subsection{Antagonistic Activity of Endophytic Diaporthe Strain Based on Dual Culture Assay}

Antagonistic activity of endophytic Diaporthe strain was evaluated against common phytopathogens: Verticillium dahliae Kleb., Botrytis cinerea Pers., from the Fungal Collection of the Department of Agricultural Microbiology, Institute of Soil Science and Plant Cultivation, Pulawy, Poland, and Fusarium avenaceum (Fr.) Sacc., F. sporotrichioides Sherb., Alternaria alternata (Fr.) Keissl., Trichothecium roseum (Pers.) Link from the Fungal Collection of Phytopathology and Mycology Subdepartment, University of Life Sciences in Lublin, Poland. Endophyitic Diaporthe strain was tested using in vitro dual culture assays for its ability to inhibit the mycelial growth of common phytopathogens [41]. Five-milliliter plugs of endophyte and pathogen were co-cultured on PDA at the two opposite ends of the $90 \mathrm{~mm}$ plates, at a distance of $40 \mathrm{~mm}$ from each other. The plates were incubated at $25^{\circ} \mathrm{C}$ for 16 days. The assay was performed in triplicate. The plates inoculated with pathogens alone served as controls. After 16 days of incubation, the radial growth of the pathogen in the presence of endophyte and the radial growth of the control colony (pathogen alone) were measured and the percentage inhibition ( $\mathrm{I} \%)$ of the average radial growth was calculated according to the following equation $[41,42]$ :

$$
\mathrm{I} \%=[(\mathrm{RC}-\mathrm{RT}) / \mathrm{RC}] \times 100
$$

$\mathrm{I} \%$ = inhibition of radial mycelial growth;

$\mathrm{RC}=$ colony radial growth of the pathogen in control plate;

$\mathrm{RT}=$ colony radial growth of the pathogen in the presence of endophyte.

Data expressed as inhibition rate (\%) of mycelial growth of all tested endophytepathogen combinations were analyzed using the GraphPad Prism 9.2.0.332 (GraphPad Holdings, San Diego, CA, USA) statistical package.

\subsection{Application of Biolog FF Plates for Catabolic Profile of Diaporthe Isolate}

The Biolog FF Plates (Biolog Inc., Hayward, CA, USA) containing 95 different carbon sources were used. The inoculation step was performed following the manufacturer's protocol. Mycelium from single spore cultures growth on PDA at $22{ }^{\circ} \mathrm{C}$ for 21 days was homogenized in inoculating fluid FF (IF-FF, Biolog Inc., Hayward, CA, USA), and the cell density was adjusted to $75 \%$. Each well of the Biolog FF Plates was inoculated by $100 \mu \mathrm{L}$ of the mycelium suspension, and the plates were incubated in an OmniLog incubator at $28^{\circ} \mathrm{C}$ for 10 days. The experiment was done in three replicates. Each replicate was read every $15 \mathrm{~min}$. The obtained results were analyzed using $\mathrm{R}$ package 4.0.3.

\section{Results}

\subsection{Identification of Endophytic Diaporthe Strain}

The endophyte grown on PDA medium at $25{ }^{\circ} \mathrm{C}$ formed a colony typical of the genus Diaporthe with creamy white compact mycelium forming characteristic rings with darker beige pigmentation at the center (Figure 1a,b) but sporulation of this strain was not observed. 


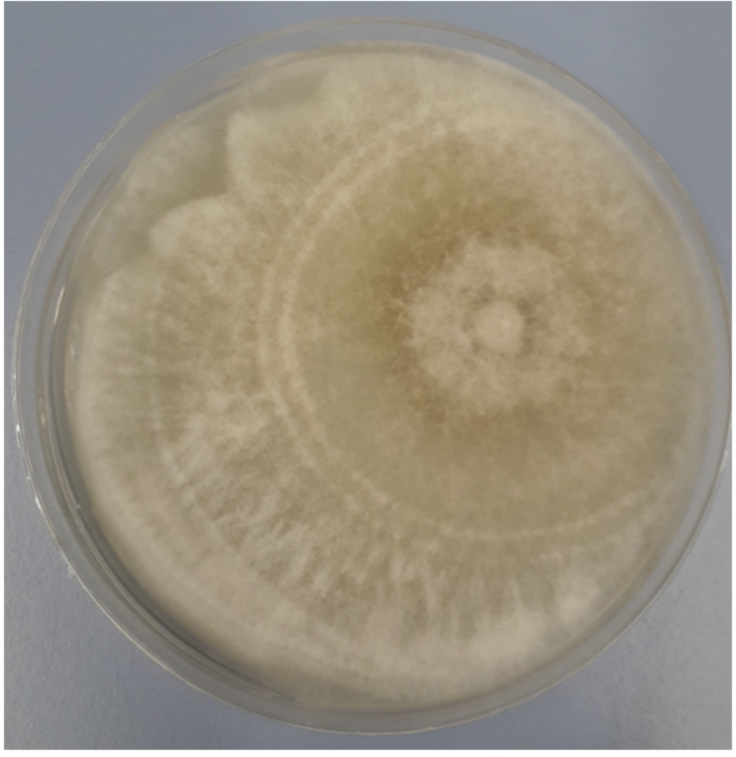

(a)

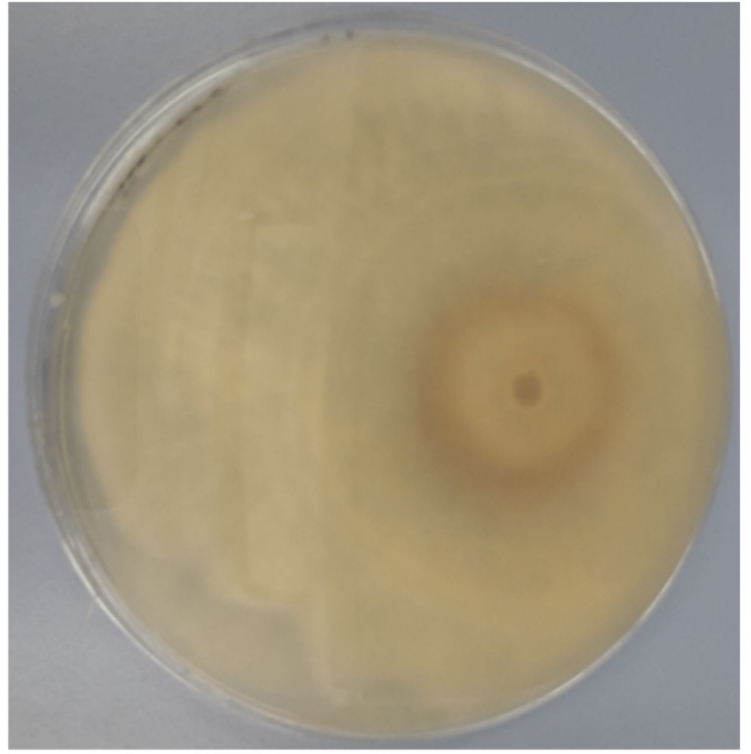

(b)

Figure 1. Fourteen-day-old culture of endophytic Diaporthe on PDA (a) avers; (b) reverse (photo by B. Abramczyk).

The endophyte was further identified based on ITS, TEF, TUB, and CAL genes. The obtained sequences were blasted against the nucleotide database of NCBI, and the closest related species were obtained. The endophytic Diaporthe strain was assigned to D. eres with $100 \%$ of similarity for all analyzed loci. The results of the BLASTn analysis are shown in Table 1.

Table 1. Species most closely related to endophytic Diaporthe based on ITS, TEF, TUB, and CAL sequences using BLASTn analysis.

\begin{tabular}{ccccc}
\hline LOCUS & GenBank Accession No. & Closest Related Species & Similarity [\%] & Coverage [\%] \\
\hline ITS & MW664034 & D. eres EU571099 & 100 & 99.8 \\
TEF & OK506723 & D. eres JF461475 & 100 & 100 \\
TUB & OK506724 & D. eres MG281207 & 100 & 100 \\
CAL & OK490500 & D. eres MH051294 & 100 & 100 \\
\hline
\end{tabular}

\subsection{Antagonistic Activity}

The radial growth inhibition percentage (I\%) was calculated for each endophytepathogen combination and summarized in Table 2.

Table 2. Mycelial growth inhibition percentage (I\%) after 16 days of incubation.

\begin{tabular}{cc}
\hline Pathogen & Inhibition Rate (I\%) \\
\hline A. alternata & 32.04 \\
B. cinerea & 29.20 \\
F. avenaceum & 33.40 \\
F. sporotrichioides & 27.84 \\
T. roseum & 40.68 \\
V. dahliae & 20.68 \\
\hline
\end{tabular}

Dual culture assay revealed the inhibition percentage of endophytic $D$. eres strain against all tested plant pathogens but there was no complete inhibition of growth observed in any dual culture combination. The I\% ranged between $20.68 \%$ and $40.68 \%$. The highest 
$\mathrm{I} \%$ was observed in combination with $T$. roseum and the lowest $\mathrm{I} \%$ with $V$. dahliae as compared to the control (Table 2, Figure 2). Moreover, a distinct zone of inhibition occurred between the Diaporthe endophyte and the pathogens T. roseum, $V$. dahliae, and B. cinerea in the co-growth combinations (Figure $3 a, b, d$ ). However, in the remaining co-growth combinations, the contact between the hyphae of the pathogen and the endophyte was observed (Figure 3c,e,f).

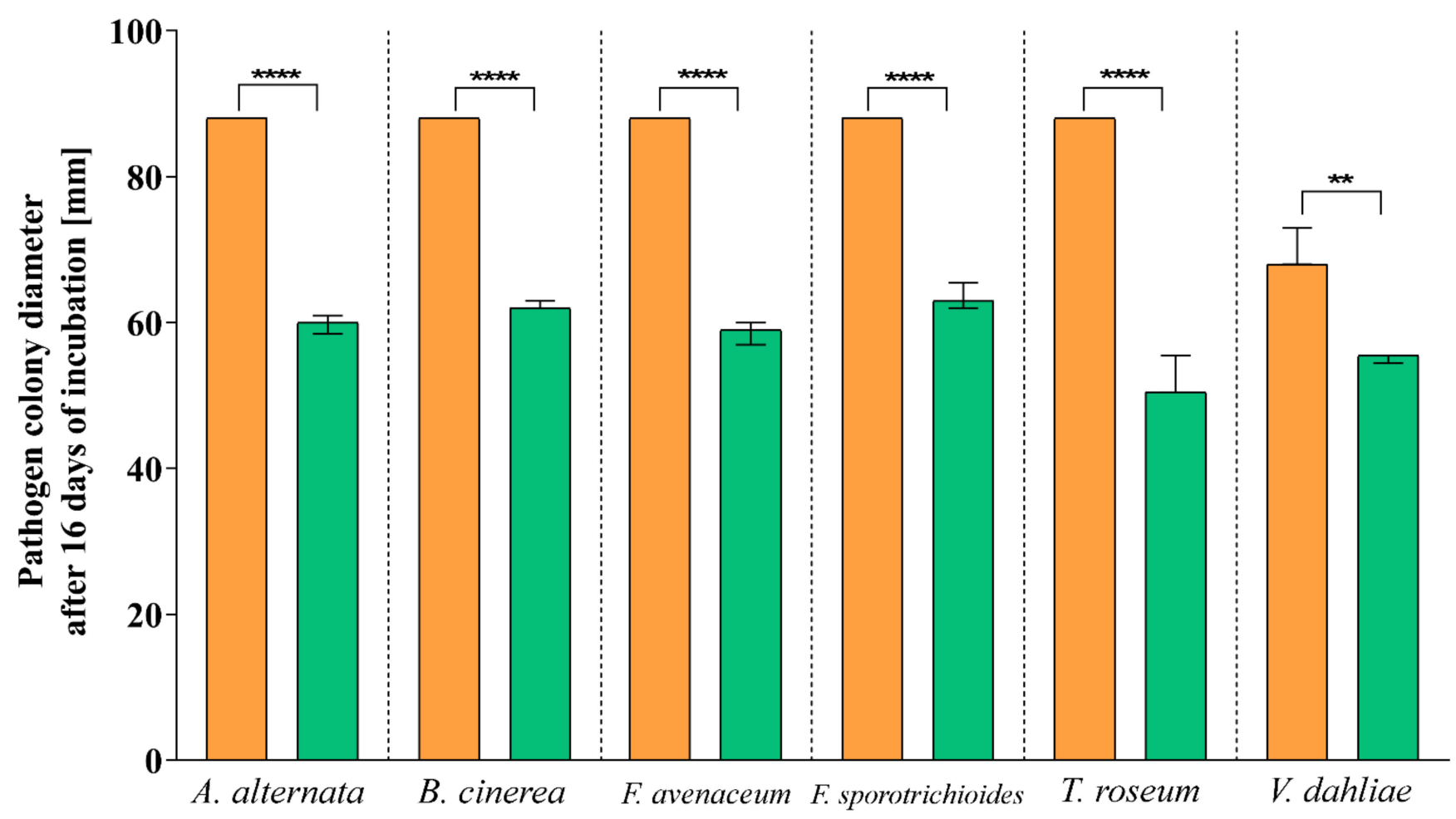

Figure 2. Diameter of the colonies of the tested pathogens after 16 days of co-growth with the endophyte. The graph presents pathogen colony diameter after 16 days of incubation in positive control (orange) and in antagonistic test plate (green). The statistical analysis was prepared with T-Student Test, $\alpha=0.05$. Statistically significant differences are marked as: ${ }^{* * *} p<0.0001,{ }^{* *} p<0.01$.

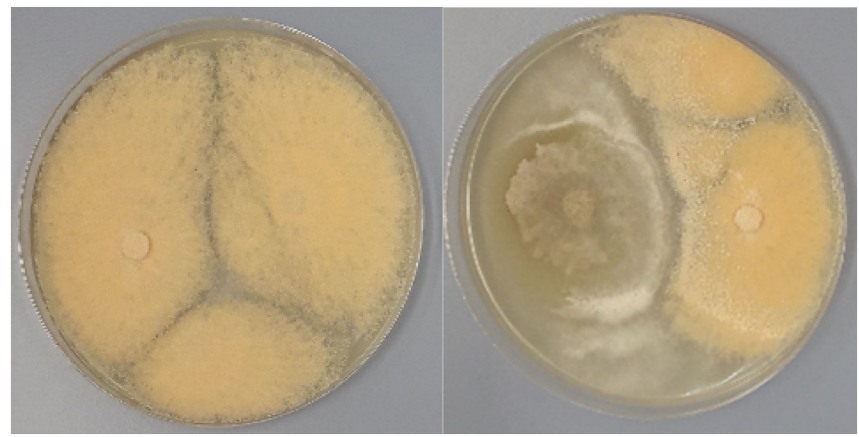

(a)

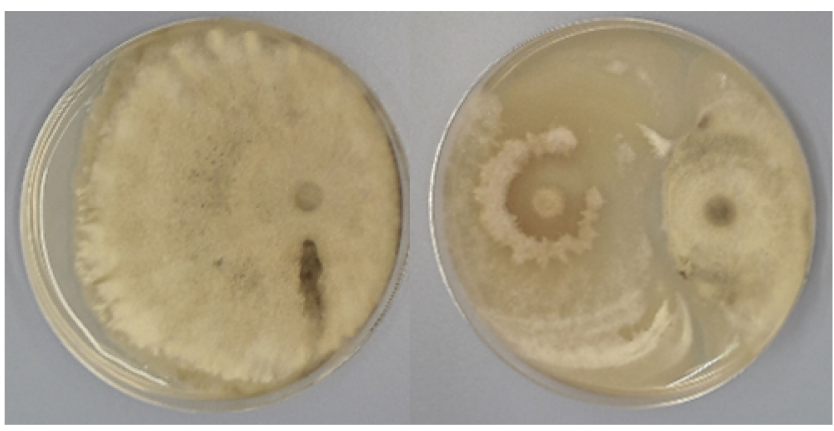

(b)

Figure 3. Cont. 


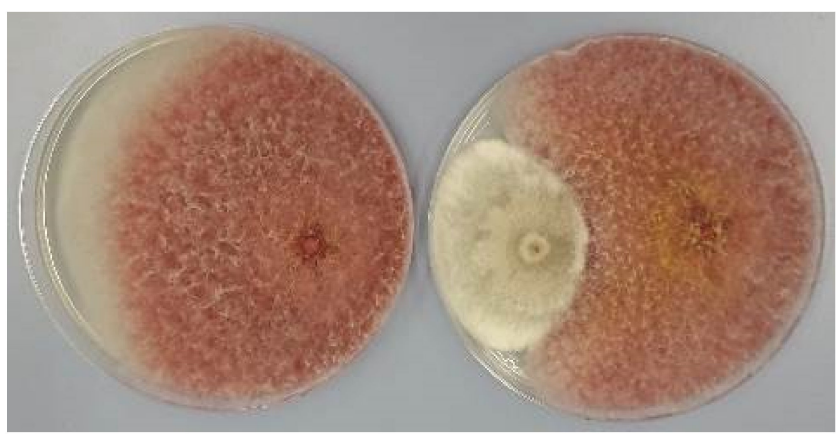

(c)

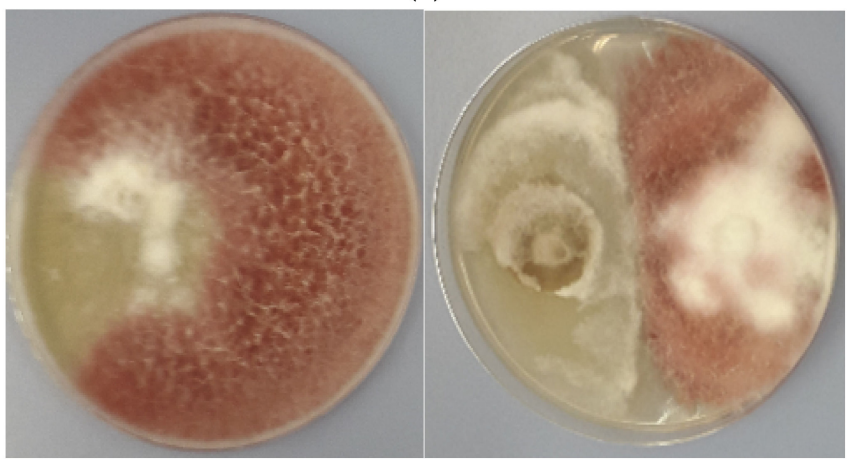

(e)

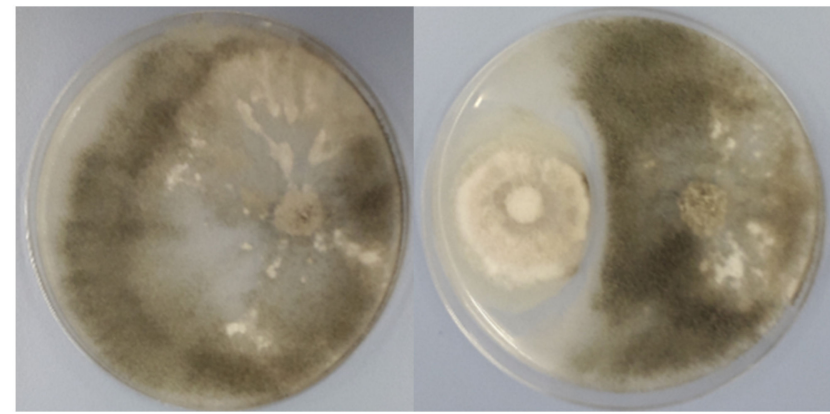

(d)

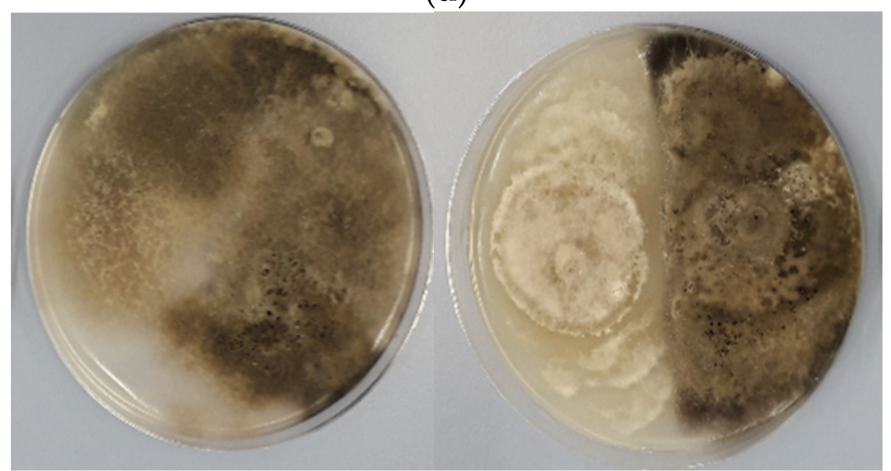

(f)

Figure 3. Dual culture assay between endophytic Diaporthe against 6 plant pathogens (a-f): (a) on the left-T. roseum as a control, on the right $-D$. eres (endophyte) with T. roseum; (b) on the left $-V$. dahliae as a control, on the right-D. eres (endophyte) with $V$. dahliae; (c) on the left $-F$. sporotrichioides as a control, on the right-D. eres (endophyte) with F. sporotrichioides; (d) on the left-B. cinerea as a control, on the right-D. eres (endophyte) with B. cinerea; (e) on the left-F. avenaceum as a control, on the right-D. eres (endophyte) with F. avenaceum; (f) on the left-A. alternata as a control, on the right-D. eres (endophyte) with A. alternata; (photo by B. Abramczyk).

\subsection{BIOLOG Analysis}

The most intensive mean utilization of carbon substrates was observed after $168 \mathrm{~h}$ of incubation; therefore, this hour was chosen to analyze the results. The growth of the analyzed strain was observed on 79 media containing 11 amino acids (L-Alanine, Ala-Gly, L-Asparagine, L-Aspartic Acid, L-Glutamic Acid, Gly-Glu, L-Ornithine, L-Phenylalanine, L-Proline, L-Serine, L-Threonine), 39 carbohydrates (N-Acetyl-D-Galactosamine, N-AcetylD-Glucosamine, N-Acetyl-b-D-Mannosamine, Adonitol, D-Arabinose, L-Arabinose, DArabitol, Arbutin, D-Cellobiose, D-Fructose, L-Fucose, b-Gentiobiose, D-Glucose, myoInositol, a-D-Lactose, Lactulose, Maltitol, D-Maltose, Maltotriose, D-Mannitol, D-Melezitose, a-Methyl-D-Galactoside, b-Methyl-D-Galactoside, a-Methyl-D-Glucoside, b-Methyl-DGlucoside, Palatinose, D-Psicose, D-Raffinose, L-Rhamnose, D-Ribose, Sedoheptulosan, D-Sorbitol, Stachyose, Sucrose, D-Tagatose, D-Trehalose, Turanose, Xylitol, D-Xylose), 14 carboxylic acids (D-Galacturonic Acid, D-Gluconic Acid, D-Glucuronic Acid, 2-Keto-DGluconic Acid, b-Hydroxy-Butyric Acid, a-Keto-Glutaric Acid, L-Lactic Acid, D-Malic Acid, L-Malic Acid, Quinic Acid, D-Saccharic Acid, Sebacic Acid, Succinic Acid, NAcetyl-L-Glutamic Acid), 8 miscellaneous (a-D-Glucose-1-Phosphate, Glycerol, D-Salicin, Bromo-Succinic Acid, D-Lactic Acid Methyl Ester, Adenosine, Uridine, Adenosine-5'Monophosphate), 3 amines and amides (L-Alaninamide, Ethanolamine, Putrescine), and 4 polymers (Tween 80, a-Cyclodextrin, b-Cyclodextrin, Glycogen) (Figure 4). 


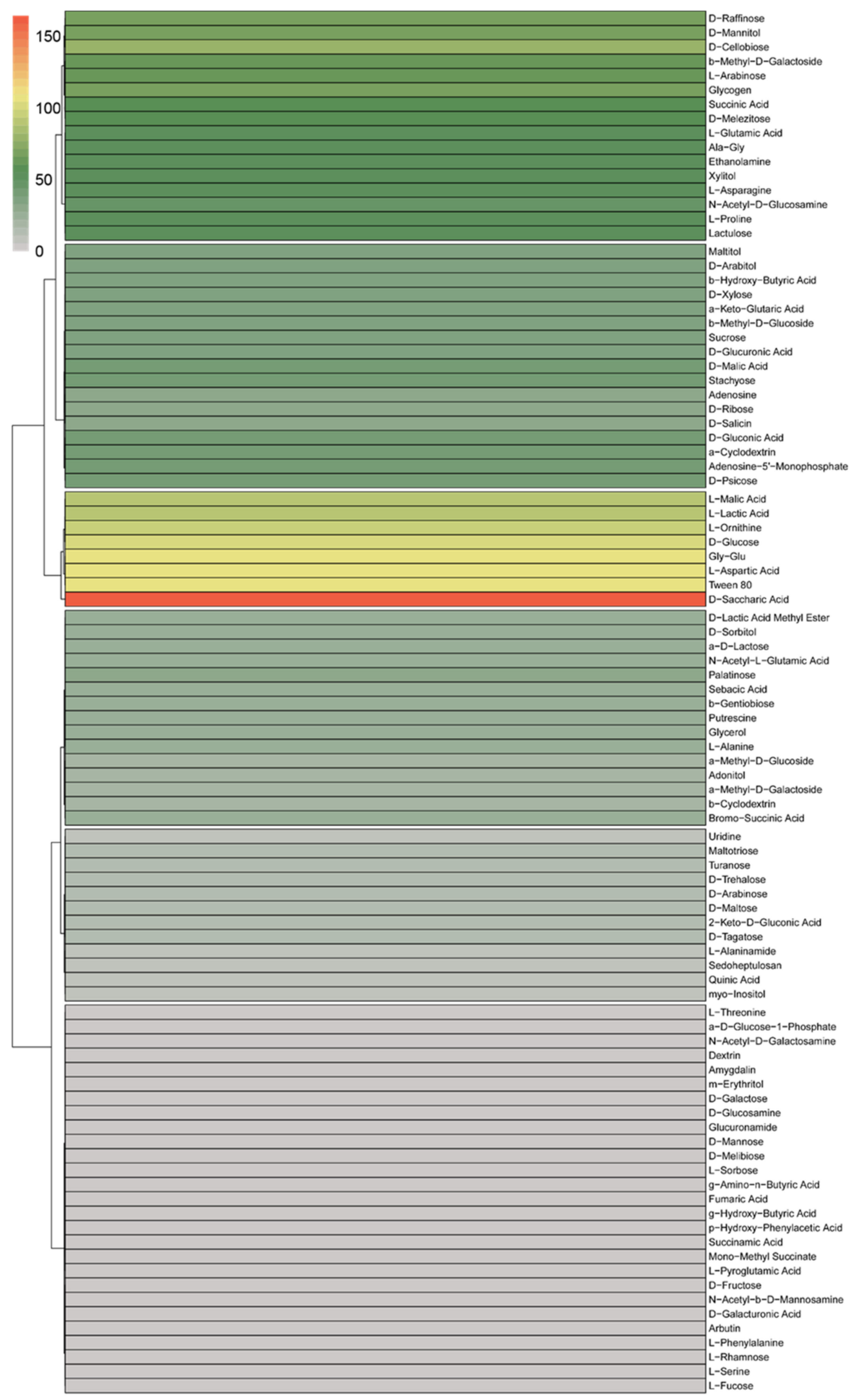

Figure 4. The heatmap presenting utilization of all substrates by analyzed endophytic strain (168 h of incubation).

Biolog FF Plate analysis using the OmniLog platform and Retrospect software allows observation of the changes that occur over time and the kinetics of the decomposition of 
individual substrates. The results of the decomposition of the substrates were analyzed at $24 \mathrm{~h}$ intervals ( $24 \mathrm{~h}$ to $168 \mathrm{~h}$ ). After $24 \mathrm{~h}$, decomposition was observed in 19 substrates $(20 \%)$, after 48 h, 22 substrates ( $23.16 \%$ ); after 72 h, 29 substrates (30.53\%); after 96 h, 46 substrates (48.42\%); after 120 h, 59 substrates (62.10\%); after $144 \mathrm{~h}, 74$ substrates $(77.90 \%)$; after $168 \mathrm{~h}$, 79 substrates $(83.16 \%)$. The wells in which the fastest growth (before $12 \mathrm{~h}$ of incubation) was observed were: Tween 80, D-Arabinose, L-Arabinose, D-Arabitol, D-Cellobiose, aCyclodextrin, b-Cyclodextrin, D-Fructose, D-Galacturonic Acid, D-Glucose, Maltotriose, D-Ribose, D-Xylose, L-Malic Acid, Quinic Acid, Sebacic Acid, L-Glutamic Acid, Uridine, and Adenosine-5'-Monophosphate. The decomposition of N-Acetyl-D-Galactosamine, Dextrin, m-Erythritol, D-Galactose, D-Glucosamine, Glucuronamide, D-Mannose, L-Sorbose, g-Amino-n-Butyric Acid, Fumaric Acid, g-Hydroxy-Butyric Acid, p-Hydroxy-Phenylacetic Acid, Succinamic Acid, Mono-Methyl Succinate, L-Phenylalanine, L-Pyroglutamic Acid, L-Threonine characterized the smallest efficiency (mean efficiency $<1$ ). The highest decomposition was observed in the well with D-Saccharic Acid (mean efficiency > 50) (Figure 4).

The most effective decomposition of analyzed substrates after $240 \mathrm{~h}$ of incubation was observed in polymers (mean efficiency $=61.40$ ) and amino acids groups (mean efficiency $=63.54)$, and the least, amines and amides (mean efficiency $=33.78)$ (Figure 5).

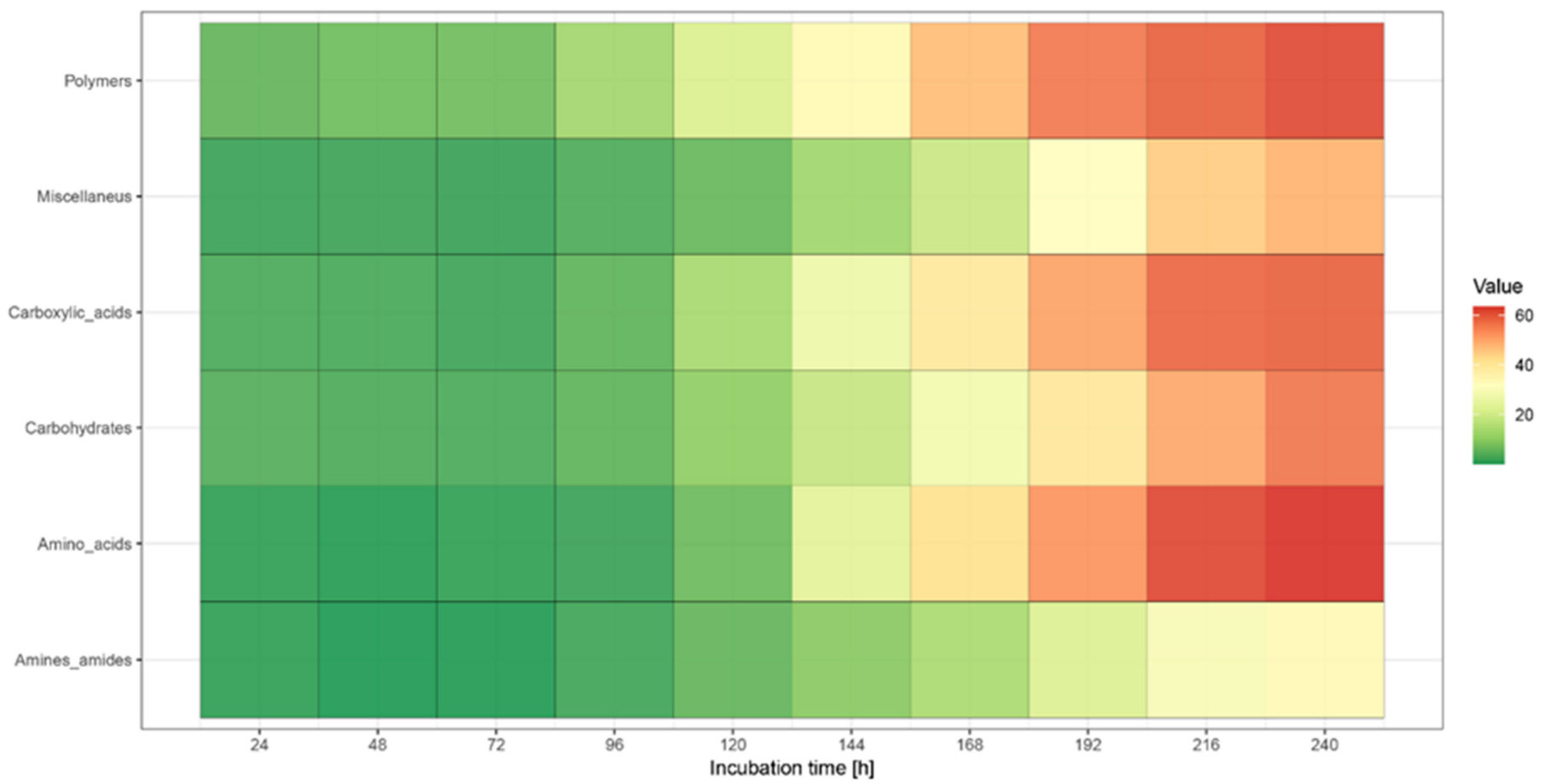

Figure 5. Heatmap presenting utilization of different groups of substrates by analyzed endophytic strain.

\section{Discussion}

Excessive use of agrochemicals has contributed to the environmental pollution and development of pathogen resistance. Therefore, alternative methods to combat pathogens and sustain agriculture are important and have received more attention in the past decade [9]. Endophytes that reside asymptomatically within a plant can make the chemical intensive crop production system more sustainable as they have the ability to enhance plant growth and increase plant fitness by providing biotic and abiotic stress tolerance and have the potential to provide a source of candidate strains for biocontrol applications $[6,9,43]$.

Our research describes for the first time the endophytic $D$. eres, whose occurrence on P. domestica in Poland has been previously reported [14] but its characterization has not been performed before. The identification of the strain was confirmed based on morphological features and sequence data analysis of ITS, TEF, TUB, and CAL genes in accordance with other scientists' research where the delimitation of species within the genus Diaporthe only 
proved satisfactory once morphology combined with multi-gene DNA sequence data were analyzed [13,15,17-29].

The antagonistic activity test revealed the ability of $D$. eres to reduce the growth of all tested phytopathogens with the mycelial growth inhibition percent (I\%) ranging from $20.68 \%$ to $40.68 \%$. The highest I \% was observed in combination with T. roseum ( $40.68 \%$ ), followed by F. avenaceum (33.40\%) and A. alternata (32.04\%), a slightly lower I\% with B. cinerea $(29.20 \%)$ and F. sporotrichioides $(27.84 \%)$, whereas the lowest I\% was recorded for V. dahliae $(20.68 \%)$. The literature contains information about the occurrence of endophytic D. eres on other species of woody plants, including the branches of Fagus sylvatica in Poland, Germany [44], and Switzerland [45,46]; leaves of Acer macrophyllum in British Columbia [46,47]; barks of Taxus chinensis in China [48]; leaves and branches of Quercus cerris in Italy [49]; and leaves of Larix koempferi and Pinus densiflora in Korea [50]. However, the authors cited did not investigate the antagonistic activity of these strains.

In our study, the type of interaction between the endophytic Diaporthe strain and pathogens was the limitation of mycelium growth by contact, which suggests that competition for space was the main mechanism of action [51]. However, endophytic fungus also formed the inhibition zones with some pathogens in dual cultures. This fact indicates that the endophyte might reduce the pathogen growth by producing certain metabolites, rather than by competition or parasitism. In fact, the antagonistic properties of microorganisms that act as biocontrol agents are based on the activation of multiple mechanisms. They can control pathogens by competing for nutrients and space, by mycoparasitism, antibiosis, or metabolite production, by affecting the pathogen, or by promoting plant growth and defense mechanisms [52-54].

Several studies have investigated the in vitro activity of other Diaporthe endophytes against various plant pathogens. Santos et al. [6] demonstrated the ability of Diaporthe endophytes isolated from leaves of Sapindus saponaria to reduce the growth of phytopathogens Fusarium solani, Moniliophthora perniciosa, and Glomeralla sp. The endophytic strain with the best result was Diaporthe citri with a $67.50 \%$ inhibition rate against $F$. solani followed by Diaporthe phaseolorum with $64.80 \%$ against M. perniciosa. In another study, Santos et al. [55] proved an inhibitory effect of new endophytic Diaporthe species (D. terebinthifolii and D. endophytica) from medicinal plants Schinus terebinthifolius and Maytenus ilicifolia, respectively, described earlier by Gomes et al. [13] against citrus pathogen Phyllosticta citricarpa in vitro and in detached fruits. Moreover, the endophytic Diaporthe strains from Pachystachys lutea were effective against F. oxysporum and Colletotrichum sp. [51] and the antifungal activity of D. citri, isolated from Mikania glomerata, was verified by in vitro tests against Fusarium solani and Didymella bryoniae [56]. Similarly Diaporthe phaseolorum isolated from Espeletia sp. demonstrated significant activity against the plant pathogen Phytophthora infestans [57]. Furthermore, the antifungal effects of D. phaseolorum strains on Ganoderma boninense were established using the dual culture test [58]. Some compounds obtained from Diaporthe have also demonstrated potent antifungal and antibacterial activity against Gram-positive and Gram-negative bacteria $[51,56,59,60]$. On the other hand, Tanney et al. [60] showed antifungal activity of Diaporthe maritima from Picea spp., and their crude extracts on the growth of the biotrophic pathogen Microbotryum violaceum and the yeast Saccharommyces cerevisiae. Among endophytic fungi, Diaporthe longicolla exhibited moderate activity with growth inhibition ranging between $11.20 \%$ and $61.95 \%$ against the tested phytopathogens [61].

The possibility of pathogen control by the Phomopsis-like morph has also been found. Antifungal metabolites of Phomopsis sp. from Gossypium hirsutum limited the growth of pathogenic fungi: Sclerotinia sclerotiorum, Bipolaris maydis, Fusarium oxysporum, Botrytis cinerea, Bipolaris sorokiniana, Gaeumannomyces graminis var. tritici, and Rhizoctonia cerealis [62]. On the other hand, Phomopsis oblonga (anamorph of Diaporthe eres) colonizing Ulmus tree overgrows the mycelium of pathogens Ophiostoma ulmi and Ophiostoma novoulmi. It is possible that through the colonization of Phomopsis oblonga bark and phloem of elms is un-attractive for the invasion and reproduction of Dutch Elm Disease vectors, namely Scoltus spp. Thus, the beetles do not spread conidia of Ophiostoma spp. to other 
living trees $[30,63]$. The defense of insects most likely relies on the action of fungal toxins. It can be assumed that $D$. eres also produces such toxins in beech leaves [45].

The use of antagonistic endophytes as biocontrol agents is an attractive option for the management of some plant diseases, resulting in a minimal impact on the environment. When testing endophytic fungi for antagonistic potential, it is important to determine the nutritional preference of the fungus with a view to discovering a promising candidate for the future commercial production of new endophyte-based biopreparations. In our preliminary studies, the Biolog FF Plates method was used to determine the ability of endophytic $D$. eres strain to use different carbon sources. This system is a rapid method for the analysis of the catabolic potential of a fungal community or fungal strain pure culture based on their abilities to utilize 95 carbon substrates [64]. The BIOLOG method has been applied previously to assess functional diversity and nutritional profiles of individual fungal species $[65,66]$, to test the nutritional competition between fungal pathogens and beneficial strains [67], and to distinguish closely related cultures [64,68-70].

Although the BIOLOG system has been used in many studies on the physiological characteristics of different fungal species, as far as we know, no data are available on the use of such method to study the biology of Diaporthe species.

Our preliminary study revealed that the endophytic $D$. eres strain has the ability to utilize a broad range of carbon sources. This may contribute to the polymorphic nature of the fungus, being one of the reasons why Diaporthe spp. Colonize a wide range of host plants and can be found in various climate zones around the world [10,12]. De la Cruz et al. [68] observed the same trend for the marine fungus Dendryphiella during the investigation of carbon source utilization by two marine species of this fungus. In our study, the endophytic strain mainly degraded carbohydrates and carboxylic acids, which are the main sources of metabolic changes in cells [71], but other carbon sources such as amino acids and polymers have also been consumed. Similarly, in the study by Barrera et al. [66] on the carbon assimilation by 10 strains from the genus Cladorrhinum, carbohydrates were mainly utilized by most strains. Only three strains, C. foecundissimum CBS 180.66, C. samala INTA-AR 1, and C. bulbillosum INTA-AR 54, used mainly esters or polymers.

Species of Diaporthe are a major group of endophytes in stems and leaves of angiosperms in both tropical and temperate ecosystems $[12,31,72,73]$. It has been shown that some of them have the ability to switch between life-styles. The same species can be found on the same or other hosts in different life modes [12]. Examples of phytopathogens reported as endophytes comprise some Diaporthe species, frequently present in asymptomatic tissues of a wide variety of plant species [74]. For instance, D. eres occurs as pathogen on a wide range of plant hosts throughout the world, including economically important fruit trees and ornamentals $[13,23,75]$ and as endophyte on $P$. domestica in a previous [14] and the present study. Furthermore, D. foeniculina, generally accepted as an opportunistic pathogen on various herbaceous weeds, ornamentals, and fruit trees [22], has also been found as an endophyte occurring on a wide range of tropical trees [22]. Huang et al. [20] observed that some Diaporthe species associated with citrus in China acted as opportunistic plant pathogens as well. Moreover, the study by Dong et al. [76] revealed the existence of several previously known pathogenic Diaporthe species as endophytes on citrus. For instance, D. limonicola isolated form C. grandis "Tomentosa" leaves as endophyte was first reported as a dieback pathogen of lemon trees in Europe [77]. Two other species, D. masirevicii and D. perseae, have been reported as pathogens on several other hosts [78-81]. Results obtained by Sessa et al. [74] have demonstrated that healthy apple, pear, blueberry, and peach shoots can host many known endophytic fungi, including Diaporthe, along with potential wood disease-causing fungi that should be regarded as latent pathogens [74]. D. amygdali, the well-known and highly frequent pathogen associated with constriction canker in peach shoots, and $D$. eres, associated with cankers in young apple trees, were not recovered as latent pathogens from any of the hosts. Possible explanations for these notorious absences could be that these pathogenic species have a very short latent stage and therefore would be less likely to be present in the sampled asymptomatic twigs, or that 
they are actually outcompeted by true endophytes in young intact branches [74]. Although Diaporthe was also a highly frequent genus, represented by 10 species, two of the most well-known pathogenic species $D$. amygdali and $D$. eres were not detected in asymptomatic twigs, and only three species (D. infecunda, D. serafiniae and D. oxe) could be considered as latent pathogens [74]. Identification of previously known pathogenic species as endophytes might reveal the opportunistic pathogenic nature of Diaporthe species [82].

Although the species of Diaporthe can be found occupying different life modes in nature, so far, the factor that drives them into pathogenicity from endophytes has not been confirmed [20]. Mostly, the outcome of interactions relies on the environmental factors and the genotype of both the host and the interacting microorganism [83]. Furthermore, the successful colonization by endophytes is affected by the plant tissue type, the microbial taxon and strain type, and other biotic and abiotic factors [84]. As a result of adaptation to these different environmental conditions, different fungi forming distinctive endophytic communities are specific to each environmental condition and tissue type. Besides geographic areas and plant tissues exert influences on endophytic fungal communities, isolation strategies (e.g., media nutrient composition) often gives preference to certain fungal groups [85]. Host preference is an important parameter for both parasitic and symbiotic plant-fungal interactions [86]. Some species of Diaporthe may be either pathogenic or harmless endophytes, depending on the type of host and the health of the host [13]. In general, changing of lifestyle from endophytic to pathogenic or vice versa when colonizing its host might be due to the disruption of a balanced communication with its host factor [87]. Therefore, different environmental pressures can select endophytes with different physiological abilities, such as enzyme production and antagonistic activity against phytopathogens of economically important plant cultivars [51]. The ability to enter and thrive in host tissues makes endophytes unique, showing multidimensional interactions within the host plant [88].

The number of reports of endophytic Diaporthe species is high, and works have focused on their potential as producers of novel enzymes and secondary metabolites with antibiotic, fungicidal, or anticarcinogenic activity [74]. Our current knowledge concerning ecology and biology of endophytic Diaporthe species is just the "tip of the iceberg" and much similar work should be focused on collecting more endophytic Diaporthe from wide geographic regions. Since concept of species in the genus Diaporthe has now been more clearly defined based on multi-locus phylogeny, new species recognition and species redefinition are the main areas for future taxonomic work on Diaporthe [89].

\section{Conclusions}

Sequence analyzes confirmed that the endophytic strain inhabiting P. domestica shoots belongs to the $D$. eres species complex. The research using the BIOLOG system focused mainly on comparing several strains within the same or different species. Therefore, our preliminary research using only one Diaporthe strain should be treated as an introduction to further analyses of a larger group of this species. The species where only one isolate was tested should be studied in more detail. Further studies are necessary to understand factors that determine the pathogenicity of endophytic Diaporthe strains towards fruit trees. Therefore, better knowledge of endophytic Diaporthe communities that thrive in phyllosphere of orchard plants is needed. This would be useful for achieving a better understanding of factors that influence Diaporthe endophytes composition, the structure and the ability to switch life modes in order to predict their response to climate change. By identifying factors that play a dominant role in the structure of Diaporthe endophytes communities in orchard plants, novel strategies could be developed for mitigating the impacts of climate change and for improving the fruit farming.

Since the endophytic $D$. eres strain could be considered a promising option for plant disease management in the future, further research is required to investigate more isolates of this species for their metabolite production and biocontrol potential. 


\begin{abstract}
Author Contributions: Conceptualization, B.A.; methodology, B.A., A.M.-G., E.K.; investigation, B.A., A.M.-G.; validation, B.A.; formal analysis A.M.-G., J.G.; resources, B.A., E.K., A.G.; data curation, B.A., A.M.-G.; writing—original draft preparation, B.A.; writing—review and editing, B.A., A.M.-G., E.K.; visualization, B.A.; supervision, E.K., A.G., W.O.; project administration, B.A.; funding acquisition, B.A. All authors have read and agreed to the published version of the manuscript.
\end{abstract}

Funding: This research was funded by the National Science Centre, Poland, the grant number 2016/21/N/NZ9/01526.

Data Availability Statement: Data are contained within the article.

Conflicts of Interest: The authors declare no conflict of interest.

\title{
References
}

1. Arnold, A.E.; Mejia, L.C.; Kyllo, D.; Rojas, E.I.; Maynard, Z.; Robbins, N.; Herre, E.A. Fungal endophytes limit pathogen damage in a tropical tree. Proc. Natl. Acad. Sci. USA 2003, 100, 15649-15654. [CrossRef]

2. Doty, L.S. Growth-promoting endophytic fungi of forest trees. In Endophytes of Forest Trees: Biology and Applications, Forestry Sciences 80; Pirttilä, A.M., Frank, A.C., Eds.; Springer Science, Business Media: Berlin/Heidelberg, Germany, 2011 ; pp. 151-156.

3. Rakshith, D.; Santosh, P.; Satish, S. Isolation and characterization of antimicrobial metabolite producing endophytic Phomopsis sp. from Ficus pumila Linn. (Moraceae). Int. J. Chem. Anal. Sci. 2013, 4, 156-160. [CrossRef]

4. Khan, A.L.; Hussain, J.; Al-Harrasi, A.; Al-Rawahi, A.; Lee, I.J. Endophytic fungi: Resource for gibberellins and crop abiotic stress resistance. Crit. Rev. Biotechnol. 2015, 35, 62-74. [CrossRef] [PubMed]

5. Dutta, D.; Puzari, K.C.; Gogoi, R.; Dutta, P. Endophytes: Exploitation as a Tool in Plant Protection. Braz. Arch. Biol. Technol. 2014, 57, 621-629. [CrossRef]

6. Santos, C.M.; da Silva, R.A.; Garcia, A.; Polli, A.D.; Polonio, J.C.; Azevedo, J.L.; Pamphile, J.A. Enzymatic and antagonist activity of endophytic fungi from Sapindus saponaria L. (Sapindaceae). Acta Biol. Colomb. 2019, 24, 322. [CrossRef]

7. Petrini, O.; Sieber, T.N.; Toti, L.; Viret, O. Ecology, metabolic production, and substrate utilization in endophytic fungi. Nat. Toxins 1992, 1, 185-196. [CrossRef]

8. Hyde, K.D.; Soytong, K. The fungal endophyte dilemma. Fungal Divers. 2008, 33, 163-173.

9. De Silva, N.I.; Brooks, S.; Lumyong, S.; Hyde, K.D. Use of endophytes as biocontrol agents. Fungal Biol. Rev. 2019, 33, 133-148. [CrossRef]

10. Chepkirui, C.; Stadler, M. The genus Diaporthe: A rich source of diverse and bioactive metabolites. Mycol. Prog. 2017, 16, 477-494. [CrossRef]

11. Xu, T.-C.; Lu, Y.-H.; Wang, J.-F.; Song, Z.-Q.; Hou, Y.-G.; Liu, S.-S.; Liu, C.-S.; Wu, S.-H. Bioactive Secondary Metabolites of the Genus Diaporthe and Anamorph Phomopsis from Terrestrial and Marine Habitats and Endophytes: 2010-2019. Microorganisms 2021, 9, 217. [CrossRef]

12. Udayanga, D.; Liu, X.; McKenzie, E.H.C.; Chukeatirote, E.; Bahkali, A.H.A.; Hyde, K.D. The genus Phomopsis: Biology, applications, species concepts and names of common phytopathogens. Fungal Divers. 2011, 50, 189-225. [CrossRef]

13. Gomes, R.R.; Glienke, C.; Videira, S.I.R.; Lombard, L.; Groenewald, J.Z.; Crous, P.W. Diaporthe: A genus of endophytic, saprobic and plant pathogenic fungi. Persoonia 2013, 31, 1-41. [CrossRef]

14. Król, E.D.; Abramczyk, B.A.; Zalewska, E.D.; Zimowska, B. Fungi inhabiting fruit tree shoots with special reference to the Diaporthe (Phomopsis) genus. Acta Sci. Pol. Hortorum Cultus 2017, 16, 113-126. [CrossRef]

15. Santos, L.; Alves, A.; Alves, R. Evaluating multi-locus phylogenies for species boundaries determination in the genus Diaporthe. Peer] 2017, 5, e3120. [CrossRef]

16. Abramczyk, B.A.; Król, E.D.; Zalewska, E.D.; Zimowska, B. Influence of temperature and fungal community on growth and sporulation of Diaporthe from fruit plants. Acta Sci. Pol. Hortorum Cultus 2020, 19, 71-79. [CrossRef]

17. Sun, W.; Huang, S.; Xia, J.; Zhang, X.; Li, Z. Morphological and molecular identification of Diaporthe species in south-western China, with description of eight new species. MycoKeys 2021, 77, 65-95. [CrossRef] [PubMed]

18. Baumgartner, K.; Fujiyoshi, P.T.; Travadon, R.; Castlebury, L.A.; Wilcox, W.F.; Rolshausen, P.E. Characterization of species of Diaporthe from wood cankers of grape in eastern North American vineyards. Plant Dis. 2013, 97, 912-920. [CrossRef]

19. Huang, F.; Hou, X.; Dewdney, M.M.; Fu, Y.; Chen, G.Q.; Hyde, K.D.; Li, H. Diaporthe species occurring on Citrus in China. Fungal Divers. 2013, 61, 237-250. [CrossRef]

20. Huang, F.; Udayanga, D.; Wang, X.H.; Hou, X.; Mei, X.F.; Fu, Y.S.; Hyde, K.D.; Li, H.Y. Endophytic Diaporthe associated with Citrus: A phylogenetic reassessment with seven new species from China. Fungal Biol. 2015, 119, 331-347. [CrossRef]

21. Tan, Y.P.; Edwards, J.; Grice, K.R.E.; Shivas, R.G. Molecular phylogenetic analysis reveals six new Diaporthe species from Australia. Fungal Divers. 2013, 61, 251-260. [CrossRef]

22. Udayanga, D.; Castlebury, L.A.; Rossman, A.Y.; Chukeatirote, E.; Hyde, K.D. Insights into the genus Diaporthe: Phylogenetic species delimitation in the D. eres species complex. Fungal Divers. 2014, 67, 203-229. [CrossRef]

23. Udayanga, D.; Castlebury, L.A.; Rossman, A.Y.; Hyde, K.D. Species limits in Diaporthe: Molecular reassessment of D. citri, D. cytosporella, D. foeniculina and D. rudis. Persoonia 2014, 32, 83-101. [CrossRef] [PubMed] 
24. Udayanga, D.; Castlebury, L.A.; Rossman, A.Y.; Chukeatirote, E.; Hyde, K.D. The Diaporthe sojae species complex: Phylogenetic reassessment of pathogens associated with soybean, cucurbits and other field crops. Fungal Biol. 2015, 119, 383-407. [CrossRef]

25. Gao, Y.H.; Liu, F.; Duan, W.; Crous, P.W.; Cai, L. Diaporthe is paraphyletic. IMA Fungus 2017, 8, 153-187. [CrossRef] [PubMed]

26. Guarnaccia, V.; Groenewald, J.Z.; Woodhall, J.; Armengol, J.; Cinelli, T.; Eichmeier, A.; Ezra, D.; Fontaine, F.; Gramaje, D.; Gutierrez-Aguirregabiria, A. Diaporthe diversity and pathogenicity revealed from a broad survey of grapevine diseases in Europe. Persoonia 2018, 40, 135-153. [CrossRef]

27. Guo, Y.S.; Crous, P.W.; Bai, Q.; Fu, M.; Yang, M.M.; Wang, X.H.; Du, Y.M.; Hong, N.; Xu, W.X.; Wang, G.P. High diversity of Diaporthe species associated with pear shoot canker in China. Persoonia 2020, 45, 132-162. [CrossRef] [PubMed]

28. Yang, Q.; Jiang, N.; Tian, C.M. Three new Diaporthe species from Shaanxi Province, China. MycoKeys 2020, 67, 1-18. [CrossRef] [PubMed]

29. Zapata, M.; Palma, M.A.; Aninat, M.J.; Piontelli, E. Polyphasic studies of new species of Diaporthe from native forest in Chile, with descriptions of Diaporthe araucanorum sp. nov., Diaporthe foikelawen sp. nov. and Diaporthe patagonica sp. nov. Int. J. Syst. Evol. Microbiol. 2020, 70, 3379-3390. [CrossRef] [PubMed]

30. Dvořák, M.; Palovčíková, D.; Jankovský, L. The occurrence of endophytic fungus Phomopsis oblonga on elms in the area of southern Bohemia. J. For. Sci. 2006, 52, 531-535. [CrossRef]

31. Murali, T.S.; Suryanarayanan, T.S.; Geeta, R. Endophytic Phomopsis species: Host range and implications for diversity estimates Can. J. Microbiol. 2006, 52, 673-680. [CrossRef]

32. Ferreira, M.C.; Vieira, M.L.A.; Zani, C.L.; Alves, T.M.A.; Sales, J.P.A.; Murta, S.M.F.; Romanha, A.J.; Gil, L.H.V.G.; Carvalho, A.G.O.; Zilli, J.E.; et al. Molecular phylogeny, diversity, symbiosis and discover of bioactive compounds of endophytic fungi associated with the medicinal Amazonian plant Carapa guianensis Aublet (Meliaceae). Biochem. Syst. Ecol. 2015, 59, 36-44. [CrossRef]

33. Martins, F.; Pereira, J.A.; Bota, P.; Bento, A.; Baptista, P. Fungal endophyte communities in above-and belowground olive tree organs and the effect of season and geographic location on their structures. Fungal Ecol. 2016, 20, 193-201. [CrossRef]

34. Hanácková, Z.; Havrdová, L.; Cerný, L.; Zahradník, D.; Koukol, O. Fungal Endophytes in Ash Shoots-Diversity and Inhibition of Hymenoscyphus fraxineus. Balt. For. 2017, 23, 89-106.

35. Ignjatović, J.; Maljurić, N.; Golubović, J.; Ravnikar, M.; Petković, M.; Savodnik, N.; Štrukelj, B.; Otašević, B. Characterization of Biomolecules with Antibiotic Activity from Endophytic Fungi Phomopsis Species. Acta Chim. Slov. 2020, 67, 445-461. [CrossRef]

36. Król, E. Grzyby zasiedlające zdrowe łozy winorośli (Vitis spp.) w wybranych szkółkach. Acta Agrobot. 2006, 59, 163-173. [CrossRef]

37. Castillo-Pando, M.S.; Nair, N.G.; Emmett, R.W.; Wicks, T.J. Inhibition in pycnidial viability of Phomopsis viticola on canes in situ as an aid to reducing inoculum potential of cane and leaf blight disease of grapevines. Australas. Plant Pathol. 1997, 26, 21-25. [CrossRef]

38. White, T.J.; Bruns, T.; Lee, J.; Taylor, J. Amplification and direct sequencing of fungal ribosomal RNA genes for phylogenetics. In PCR Protocols: A Guide to Methods and Applications; Innis, M.A., Gelfand, D.H., Sninsky, J.J., White, T.J., Eds.; Academic Press: San Diego, CA, USA, 1990; pp. 315-322.

39. Glass, N.L.; Donaldson, G. Development of primer sets designed for use with PCR to amplify conserved genes from filamentous ascomycetes. Appl. Environ. Microbiol. 1995, 61, 1323-1330. [CrossRef]

40. Carbone, I.; Kohn, L.M. A method for designing primer sets for speciation studies in filamentous ascomycetes. Mycologia 1999, 91, 553-556. [CrossRef]

41. Katoch, M.; Pull, S. Endophytic fungi associated with Monarda citriodora, an aromatic and medicinal plant and their biocontrol potential. Pharm. Biol. 2017, 55, 1528-1535. [CrossRef]

42. Hajieghrari, B.; Torabi-Giglou, M.; Mohammadi, M.R.; Davari, M. Biological potential of some Iranian Trichoderma isolates in the control of soil borne plant pathogenic fungi. Afr. J. Biotechnol. 2008, 7, 967-972.

43. Kaur, T. Fungal Endophyte-Host Plant Interactions: Role in Sustainable Agriculture. In Sustainable Crop Production; IntechOpen: London, UK, 2020

44. Kowalski, T.; Kehr, R.D. Endophytic fungi colonization of branch bases in several forest tree species. Sydowia 1992, 44, 137-168.

45. Sieber, T.; Hugentobler, C. Endophytische Pilze in Blattern und Asten gesunder und geschadigter Buchen (Fagus sylvatica L.). Eur. J. For. Pathol. 1987, 17, 411-425. [CrossRef]

46. Sieber, T.N. Endophytic fungi in forest trees: Are they mutualists? Fungal Biol. Rev. 2007, 21, 75-89. [CrossRef]

47. Sieber, T.N.; Dorworth, C.E. An ecological study about assemblages of endophytic fungi in Acer macrophyllum in British ColumbiaIn search of candidate mycoherbicides. Can. J. Bot. 1994, 72, 1397-1402. [CrossRef]

48. Liu, K.; Ding, X.; Deng, B.; Chen, W. Isolation and characterization of endophytic taxol-producing fungi from Taxus chinensis. J. Ind. Microbiol. Biotechnol. 2009, 36, 1171-1177. [CrossRef] [PubMed]

49. Moricca, S.; Ginetti, B.; Ragazzi, B. Species and organ-specificity in endophytes colonizing healthy and declining Mediterranean oaks. Phytopathol. Mediterr. 2012, 51, 587-598.

50. Kim, C.K.; Eo, J.K.; Eom, A.H. Diversity and seasonal variation of endophytic fungi isolated from three conifers in Mt. Taehwa, Korea. Mycobiology 2014, 41, 82-85. [CrossRef] [PubMed] 
51. Ribeiro, A.D.S.; Polonio, J.C.; Costa, A.T.; Dos Santos, C.M.; Rhoden, S.A.; Azevedo, J.L.; Pamphile, J.A. Bioprospection of culturable endophytic fungi associated with the ornamental plant Pachystachys lutea. Curr. Microbiol. 2018, 75, 588-596. [CrossRef] [PubMed]

52. Alabouvette, C.; Olivain, C.; Steinberg, C. Biological control of plant diseases: The European situation. Eur. J. Plant Pathol. 2006, 114, 329-341. [CrossRef]

53. Landum, M.; Felix, M.; Alho, J.; Garcia, R.; Cabrita, M.J.; Rei, F.; Varanda, C.M. Antagonistic activity of fungi of Olea europaea L. against Colletotrichum acutatum. Microbiol. Res. 2016, 183, 100-108. [CrossRef]

54. Jaber, L.R.; Ownley, B.H. Can we use entomopathogenic fungi as endophytes for dual biological control of insect pests and plant pathogens? Biol. Control 2018, 116, 36-45. [CrossRef]

55. Santos, P.J.; Savi, D.C.; Gomes, R.R.; Goulin, E.H.; Da Costa Senkiv, C.; Tanaka, F.A.; Almeida, Á.M.; Galli-Terasawa, L.; Kava, V.; Glienke, C. Diaporthe endophytica and D. terebinthifolii from medicinal plants for biological control of Phyllosticta citricarpa. Microbiol. Res. 2016, 186-187, 153-160. [CrossRef] [PubMed]

56. Polonio, J.C.; Almeida, T.; Garcia, A.; Mariucci, G.; Azevedo, J.; Rhoden, S.; Pamphile, J.A. Biotechnological prospecting of foliar endophytic fungi of guaco (Mikania glomerata Spreng.) with antibacterial and antagonistic activity against phytopathogens. Genet. Mol. Res. 2015, 14, 7297-7309. [CrossRef]

57. Prada, H.; Avila, L.; Sierra, R.; Bernal, A.; Restrepo, S. Caracterizacion morfologica y molecular del antagonismo entre el endofito Diaporthe sp. aislado de frailejon (Espeletia sp.) y el fitopatogeno Phytophthora infestans. (Morphological and molecular characterization of the antagonistic interaction between the endophyte Diaporthe sp. isolated from frailejon (Espeletia sp.) and the plant pathogen Phytophthora infestans). Rev. Iberoam. Micol. 2009, 26, 198-201. [CrossRef] [PubMed]

58. Cheong, S.L.; Cheow, Y.L.; Ting, A.S. Characterizing antagonistic activities and host compatibility (via simple endophyte-calli test) of endophytes as biocontrol agents of Ganoderma boninense. Biol. Control 2017, 105, 86-92. [CrossRef]

59. Li, G.; Kusari, S.; Kusari, P.; Kayser, O.; Spiteller, M. Endophytic Diaporthe sp. LG23 produces a potent antibacterial tetracyclic triterpenoid. J. Nat. Prod. 2015, 78, 2128-2132. [CrossRef] [PubMed]

60. Tanney, J.B.; McMullin, D.R.; Blake, D.; Green, B.D.; Miller, J.D.; Seifert, K.A. Production of antifungal and antiinsectan metabolites by the Picea endophyte Diaporthe maritima sp. nov. Fungal Biol. 2016, 120, 1448-1457. [CrossRef]

61. Singh, G.; Katoch, A.; Razak, M.; Kitchlu, S.; Goswami, A.; Katoch, M. Bioactive and biocontrol potential of endophytic fungi associated with Brugmansia aurea Lagerh. FEMS Microbiol. Lett. 2017, 364, fnx194. [CrossRef]

62. Fu, J.; Zhou, Y.; Li, H.F.; Ye, Y.H.; Guo, J.H. Antifungal metabolites from Phomopsis sp. By254, an endophytic fungus in Gossypium hirsutum. Afr. J. Microbiol. Res. 2011, 5, 1231-1263. Available online: https://www.academicjournals.org/ajmr (accessed on 4 December 2021). [CrossRef]

63. Webber, J.F.; Gibbs, J.N. Colonization of elm bark by Phomopsis oblonga. Trans. Br. Mycol. Soc. 1984, 82, 348-352. [CrossRef]

64. Pertile, G.; Panek, J.; Oszust, K.; Siczek, A.; Frac, M. Intraspecific functional and genetic diversity of Petriella setifera. PeerJ 2018, 6, e4420. [CrossRef]

65. Mchunu, N.P.; Permaul, K.; Alam, M.; Singh, S. Carbon utilization profile of a thermophilic fungus, Thermomyces lanuginosus using phenotypic microarray. Adv. Biosci. Biotechnol. 2013, 4, 24-32. [CrossRef]

66. Barreraa, V.A.; Martin, M.E.; Aulicino, M.; Martínez, S.; Chiessa, G.; Saparrat, M.C.N.; Gasoni, A.L. Carbon-substrate utilization profiles by Cladorrhinum (Ascomycota) Rev. Argent. Microbiol. 2019, 51, 302-306.

67. Oszust, K.; Cybulska, J.; Frac, M. How Do Trichoderma Genus Fungi Win a Nutritional Competition Battle against Soft Fruit Pathogens? A Report on Niche Overlap Nutritional Potentiates. Int. J. Mol. Sci. 2020, 21, 4235. [CrossRef]

68. Dela Cruz, T.E.E.; Schulz, B.E.; Kubicek, C.P.; Druzhinina, I.S. Carbon source utilization by the marine Dendryphiella species D. arenaria and D. salina. FEMS Microbiol. Ecol. 2006, 58, 343-353. [CrossRef] [PubMed]

69. Singh, M.P. Application of Biolog FF MicroPlate for substrate utilization and metabolite profiling of closely related fungi. J. Microbiol. Methods 2009, 77, 102-108. [CrossRef]

70. Tang, E.; Hill, C.B.; Hartman, G.L. Carbon utilization profiles of Fusarium virguliforme isolates. Can. J. Microbiol. 2010, 56, 979-986.

71. Hothersall, J.S.; Ahmed, A. Metabolic fate of the increased yeast amino acid uptake subsequent to catabolite derepression. J. Amino Acids 2013, 2013, 461901. [CrossRef] [PubMed]

72. Rossman, A.Y.; Farr, D.F.; Castlebury, L.A. A review of the phylogeny and biology of the Diaporthales. Mycoscience 2007, 48 , 135-144. [CrossRef]

73. Garcia, A.; Rhoden, S.A.; Filho, C.J.R.; Nakamura, C.V.; Pamphile, J.A. Diversity of foliar endophytic fungi from the medicinal plant Sapindus saponaria L. and their localization by scanning electron microscopy. Biol. Res. 2012, 45, 139-148. [CrossRef]

74. Sessa, L.; Abreo, E.; Lupo, S. Diversity of fungal latent pathogens and true endophytes associated with fruit trees in Uruguay. J. Phytopathol. 2018, 166, 633-647. [CrossRef]

75. Abramczyk, B.A.; Król, E.D.; Zalewska, E.D.; Zimowska, B. Morphological characteristics and pathogenicity of Diaporthe eres isolates to the fruit tree shoots. Acta Sci. Pol. Hortorum Cultus 2018, 17, 125-133. [CrossRef]

76. Dong, Z.; Manawasinghe, I.S.; Huang, Y.; Shu, Y.; Phillips, A.J.L.; Dissanayake, A.J.; Hyde, K.D.; Xiang, M.; Luo, M. Endophytic Diaporthe associated with Citrus grandis cv. Tomentosa in China. Front. Microbiol. 2021, 11, 609387. [CrossRef]

77. Guarnaccia, V.; Crous, P.W. Emerging citrus diseases in Europe caused by Diaporthe spp. IMA Fungus 2017, 8, 317-334. [CrossRef] 
78. Thompson, S.M.; Grams, R.A.; Neate, S.M.; Shivas, R.G.; Ryley, M.J.; Tan, Y.P.; Aitken, E.; Wright, G.C.; O'Connor, D.J. First reports of Diaporthe kongii, D. masirevicii, and D. ueckerae associated with stem and peg dieback on peanut in Australia. Plant Dis. 2018, 102, 1459. [CrossRef]

79. Naveen, J.; Navya, H.M.; Hithamani, G.; Niranjana, S.R.; Hariprasad, P. First report of Diaporthe masirevicii causing leaf blight of Gloriosa superba in India. New Dis. Rep. 2018, 37, 13. [CrossRef]

80. Pazdiora, P.C.; Hoffmann, J.F.; Chaves, F.C.; Dallagnol, L.J. First report of fruit rot caused by Diaporthe masirevicii on Physalis peruviana in Brazil. Plant Dis. 2018, 102, 441-442. [CrossRef]

81. Lim, L.; Mohd, M.H.; Zakaria, L. Identification and pathogenicity of Diaporthe species associated with stem-end rot of mango (Mangifera indica L.). Eur. J. Plant Pathol. 2019, 155, 687-696. [CrossRef]

82. Manawasinghe, I.S.; Dissanayake, A.J.; Li, X.; Liu, M.; Wanasinghe, D.; Xu, J.; Zhao, W.; Zhang, W.; Zhou, Y.; Hyde, K.D.; et al. High genetic diversity and species complexity of diaporthe associated with grapevine dieback in China. Front. Microbiol. 2019, 10, 1936. [CrossRef] [PubMed]

83. Brader, G.; Compant, S.; Vescio, K.; Mitter, B.; Trognitz, F.; Ma, L.J.; Sessitsch, A. Ecology and genomic insights into plantpathogenic and plant-nonpathogenic endophytes. Annu. Rev. Phytopathol. 2017, 55, 61-83. [CrossRef] [PubMed]

84. Hardoim, P.R.; Van Overbeek, L.S.; Berg, G.; Pirttilä, A.M.; Compant, S.; Campisano, A.; Döring, M.; Sessitsch, A. The hidden world within plants: Ecological and evolutionary considerations for defining functioning of microbial endophytesfining functioning of microbial endophytes. Microbiol. Mol. Biol. Rev. 2015, 79, 293-320. [CrossRef]

85. Qi, F.; Jing, T.; Zhan, Y. Characterization of endophytic fungi from Acer ginnala Maxim. in an artificial plantation: Media effect and tissue-dependent variation. PLOS ONE 2012, 7, e46785. [CrossRef]

86. Aly, A.H.; Debbab, A.; Proksch, P. Fungal endophytes: Unique plant inhabitants with great promises. Appl. Microbiol. Biotechnol. 2011, 90, 1829-1845. [CrossRef]

87. Kuo, H.C.; Hui, S.; Choi, J.; Asiegbu, F.O.; Valkonen, J.P.T.; Lee, Y. Secret lifestyles of Neurospora crassa. Sci. Rep. 2014, 4, 1-6. [CrossRef] [PubMed]

88. Mengistu, A.A. Endophytes: Colonization, Behaviour, and Their Role in Defense Mechanism. Int. J. Microbiol. 2020, $2020,6927219$. [CrossRef] [PubMed]

89. Wang, J.; Xu, X.; Mao, L.; Lao, J.; Lin, F.; Yuan, Z.; Zhang, C. Endophytic Diaporthe from Southeast China are genetically diverse based on multi-locus phylogeny analyses. World J. Microbiol. Biotechnol. 2014, 30, 237-243. [CrossRef] [PubMed] 